\title{
ANALISIS EFEK SAMPING PENGGUNAAN METODE KONTRASEPSI IMPLAN DI WILAYAH KERJA PUSKESMAS HARAPAN RAYA PEKANBARU
}

\author{
Husna Farianti Amran \\ Program Studi D-III Kebidanan STIKes Payung Negeri Pekanbaru \\ Korespondensi penulis: na.farianti@gmail.com
}

\begin{abstract}
Abstrak
Latar belakang dan tujuan: Upaya pemerintah untuk menurunkan laju pertumbuhan penduduk adalah dengan program Keluarga Berencana (KB). Implant merupakan Metode Kontrasepsi Jangka Panjang (MKJP) yang efektif, aman, dan nyaman bagi wanita. Salah satu yang mempengaruhi kepuasan dalam menggunakan Implan adalah masalah atau efek samping yang timbul. Beberapa efek samping penggunaan Implan antara lain amenore (29,5\%), perdarahan haid yg berlebihan $(18,5 \%)$, flek $(29,5 \%)$, kenaikan berat badan $(40,5 \%)$, penurunan berat badan $(14,5 \%)$, jerawat $(16,5 \%)$, Depresi $(12 \%)$. Penelitian ini bertujuan untuk menganalisis efek samping kontrasepsi implant yang meliputi gangguan siklus haid, perubahan berat badan, nyeri payudara, gangguan jerawat, dan gangguan depresi.

Metode: Jenis penelitian ini adalah kuantitaif dengan desain penelitian deskriptif. Sampel penelitian berjumlah 92 orang yang diambil dengan menggunakan teknik Simple Random Sampling. Data dikumpulkan dengan menggunakan kuesioner dan timbangan pengukur Berat Badan dan dianalisa secara Univariate.

Hasil: Hasil penelitian diperoleh efek samping penggunaan kontrasepsi Implan yang dirasakan oleh responden antara lain Gangguan Siklus Haid yaitu Amneorea sebanyak 76 responden $(82,6 \%)$, Spotting yaitu 81 responden $(88,1 \%)$, Menoragia yaitu 16 responden $(17,4 \%)$ dan siklus tidak teratur $(<20$ hari atau $>35$ hari) yaitu 16 responden $(17,4 \%)$, Efek samping Gangguan Berat Badan berupa Peingkatan Berat Badan yaitu 81 responden $(89,1 \%)$, Efek samping gangguan Nyeri Payudara yaitu 47 responden $(51,1 \%)$, Efek samping gangguan Timbulnya Jerawat yaitu 61 responden $(66,3 \%)$, dan Efek samping gangguan Depresi berupa gelisah atau gangguan emosi yaitu 87 responden $(94,6 \%)$.

Simpulan: efek samping penggunaan kontrasepsi implant adalah: Gangguan menstruasi, Gangguan berat badan, Nyeri payudara, Gangguan jerawat dan depresi. Untuk itu diharapkan bidan dalam memberikan asuhan kebidanan harus memperhatikan efek samping penggunaan kontrasepsi implant dan dapat memberikan konseling dan penatalaksanaan yang sesuai dengan efek samping yang dirasakan oleh akseptor sehingga akseptor mendapatkan asuhan lebih terfokus dan terarah.
\end{abstract}

Kata Kunci: Efek samping, Implan, Kontrasepsi

\section{Pendahuluan}

Indonesia merupakan Negara dengan jumlah penduduk ke-4 di dunia. Berdasarkan data badan pusat statistik (BPS) jumlah penduduk Indonesia tahun 2018 adalah 264,16 juta jiwa dengan jumlah penduduk laki-laki sebanyak 132,68 juta jiwa dan penduduk wanita sebanyak 131,47 juta jiwa.
(Badan Pusat Statistik, 2018). Di provinsi Riau tahun 2016 Jumlah penduduk adalah 6.500.971 jiwa, Jumlah penduduk Provinsi Riau pengalami penambahan sekitar 2.575.456 jiwa atau rata-rata 171.700 jiwa setiap tahun. (Dinkes Provinsi Riau,2016).

Upaya pemerintah untuk menurunkan laju pertumbuhan penduduk adalah dengan 
program Keluarga Berencana (KB). Program KB Nasional adalah suatu usaha untuk memenuhi kebutuhan masyarakat akan pelayanan KB dan kesehatan reproduksi yang berkualitas, menurunkan tingkat Angka Kematian Ibu dan Angka Kematian Bayi (AKI dan AKB), serta penanggulangan masalah kesehatan reproduksi dalam rangka membagun keluarga kecil berkualitas. (Noviawati,2011).

Cakupan peserta KB aktif pada Pasangan Usia Subur (PUS) tahun 2017 di Indonesia sebesar $63,22 \%$. Dalam program $\mathrm{KB}$ ada beberapa alat kontrasepsi yang dapat digunakan antara lain pil, suntikan, implant, Alat Kontrasepsi Dalam Rahim (AKDR), Metode Operasi Wanita (MOW), dan Metode Operasi Pria (MOP). (Badan Pusat Statistik,2015). Berdasarkan pemilihan jenis alat kontrasepi sebagian besar peserta $\mathrm{KB}$ aktif menggunakan alat kontrasepsi suntikan $(62,77 \%)$, pil $(17,24 \%)$, implant $(6,99 \%)$ AKDR (7,15\%), MOW (2,78\%), dan MOP $(0,53 \%)$. (Kemenkes RI,2017).

Di Provinsi Riau cakupan peserta KB Aktif sebesar 66,78\%. Berdasarkan Alat kontrasepsi yang digunakan antara lain Suntikan (26,8\%), implant (7,4\%), AKDR $(54,0 \%)$, MOW $(0,7 \%)$, dan MOP $(0,4 \%)$. Di kota Pekanbaru Penggunaan kontrasepsi Implan adalah sebesar 7.891\%. (Dinas Kesehatan Provinsi Riau: 2017)

Implant merupakan Metode Kontrasepsi Jangka Panjang (MKJP) yang berupa susuk yang terbuat dari jenis karet plastik yang berisi hormon, dipasang pada lengan atas. Implan dapat digunakan untuk jangka panjang 3-5 tahun dan bersifat reversibel. Keuntungan dari kontrasepsi implan adalah efektifitasnya tinggi sebesar 99\% untuk mencegah kehamilan selama 3 tahun (angka kegagalan implant, 1 per 100 wanita pertahun dalam 3 tahun pertama), hal ini sama dengan efektifitas AKDR, namun implan memiliki presentase kegagalan yang lebih kecil yaitu sebesar $0,05 \%$, sedangkan AKDR memiliki presentase kegagalan sebesar $0,8 \%$. (Kemenkes RI, 2013). Implan merupakan pilihan kontrasepsi yang efektif, aman, dan nyaman bagi wanita. Implan sekali terpasang tidak perlu mengingat setiap hari. Implan berisi levonorgestrel yang merupakan hormon progesterone (Handayani, S, 2010).

Salah satu yang mempengaruhi kepuasan dalam menggunakan Implan adalah masalah atau efek samping yang timbul. Beberapa efek samping penggunaan Implan antara lain gangguan sikus menstruasi, berat badan naik/turun, nyeri payudara, masalah jerawat, depresi atau yang lainnya. (Kemenkes RI, 2016). Hasil penelitian erna setiawati, (2017) Mengenai permasalahan yang timbul dalam pemakaian alat atau cara KB Implan adalah masalah atau efek samping yang timbul seperti: amenore $(29,5 \%)$, perdarahan haid yg berlebihan $(18,5 \%)$, flek $(29,5 \%)$, kenaikan berat badan $(40,5 \%)$, penurunan berat badan $(14,5 \%)$, jerawat (16,5\%), Depresi (12\%).

Dari data dinas kesehatan kota Pekanbaru tahun 2018 dengan akseptor Implan terbanyak adalah Puskesmas Harapan raya yaitu 1231 akseptor. Berdasarkan latar belakang di atas peneliti tertarik untuk melakukan penelitian dengan judul gambaran efek samping penggunaan implan di Wilayah Kerja Puskesmas Harapan Raya Tahun 2019.

\section{Metode Penelitian}

Jenis penelitian adalah kuantitatif desain deskriptif dengan pendekatan cross sectional. Penelitian dilakukan pada bulan April- Mei 2019. Populasi penelitian adalah seluruh akseptor KB Implan yang berada diwilayah kerja Puskesmas Harapan Raya Pekanbaru yang berjumlah 1231 orang, dan diambil sampel sebanyak 92 orang dengan teknik Simple Random Sampling (acak sederhana), dimana setiap populasi berkesempatan untuk menjadi sampel.

Instrumen pengumpulan data yang digunakan adalah kuesioner berupa daftar pertanyaan untuk mengetahui variabel yang diteliti yang meliputi siklus haid, nyeri payudara, gangguan jerawat, dan gangguan depresi. Sedangkan untuk mengukur berat badan akseptor digunakan timbangan berat badan. Analisa Data yang digunakan adalah analisa Univariate untuk mengetahui distribusi frekuensi responden. 


\section{Hasil dan Pembahasan}

Tabel 1. Distribusi Frekuensi Karakteristik Responden di Wilayah Kerja Puskesmas Harapan Raya Pekanbaru tahun 2019

\begin{tabular}{ccc}
\hline \multicolumn{1}{c}{ Kategori } & Jumlah & \% \\
\hline Usia & 72 & 78,3 \\
Reproduksi (20-35 tahun) & 20 & 21,7 \\
Diluar usia reproduksi (>35 tahun) & & \\
Paritas & 13 & 14,1 \\
Primigravida & 79 & 85,9 \\
Multigravida & & \\
Lama Penggunaan Implan & 76 & 82,6 \\
$\leq 3$ tahun & 16 & 17,4 \\
$>3$ tahun & & \\
\hline
\end{tabular}

Tabel 2. Distribusi Frekuensi Responden berdasarkan Efek Samping Gangguan Haid di Wilayah Kerja Puskesmas Harapan Raya Pekanbaru tahun 2019

\begin{tabular}{|c|c|c|c|}
\hline No & Kategori & Frekuensi & $\%$ \\
\hline 1 & $\begin{array}{l}\text { Gangguan siklus haid Sebelum menggunakan } \\
\text { Implan } \\
-\quad \text { Ya } \\
-\quad \text { Tidak }\end{array}$ & $\begin{array}{c}0 \\
92\end{array}$ & $\begin{array}{c}0 \\
100\end{array}$ \\
\hline 2 & Gangguan Haid Setelah menggunakan Implan & & \\
\hline & $\begin{array}{l}\text { Amenore } \\
-\quad \text { Ya } \\
-\quad \text { Tidak }\end{array}$ & $\begin{array}{l}76 \\
16 \\
\end{array}$ & $\begin{array}{l}82,6 \\
17,4 \\
\end{array}$ \\
\hline & $\begin{array}{l}\text { Spotting } \\
-\quad \text { Ya } \\
-\quad \text { Tidak }\end{array}$ & $\begin{array}{l}81 \\
11 \\
\end{array}$ & $\begin{array}{l}88,1 \\
11,9 \\
\end{array}$ \\
\hline & $\begin{array}{l}\text { Menoragia } \\
-\quad \text { Ya } \\
-\quad \text { Tidak }\end{array}$ & $\begin{array}{l}16 \\
76 \\
\end{array}$ & $\begin{array}{l}17,4 \\
82,6\end{array}$ \\
\hline & $\begin{array}{l}\text { Siklus haid tidak teratur }(<20 \text { atau }>28 \text { hari }) \\
-\quad \text { Ya } \\
-\quad \text { Tidak }\end{array}$ & $\begin{array}{l}16 \\
76\end{array}$ & $\begin{array}{l}17,4 \\
82,6\end{array}$ \\
\hline
\end{tabular}

Tabel 3. Distribusi Frekuensi Responden berdasarkan Efek Samping Perubahan Berat Badan di Wilayah Kerja Puskesmas Harapan Raya Pekanbaru tahun 2019

\begin{tabular}{|c|c|c|c|}
\hline No & 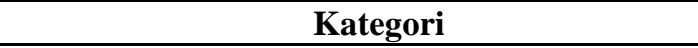 & Frekuensi & $\%$ \\
\hline \multirow[t]{3}{*}{1} & $\begin{array}{l}\text { Gangguan Berat Badan sebelum penggunaan } \\
\text { Implan }\end{array}$ & & \\
\hline & - Ya & 0 & 0 \\
\hline & - Tidak & 92 & 100 \\
\hline \multirow[t]{3}{*}{2} & $\begin{array}{l}\text { Gangguan Berat Badan setelah penggunaan } \\
\text { Implan }\end{array}$ & & \\
\hline & - Ya & 81 & 89,1 \\
\hline & - Tidak & 11 & 11,9 \\
\hline \multirow[t]{6}{*}{2} & Kenaikan / Penurunan BB & & \\
\hline & - Tidak ada kenaikan / Penurunan BB & 11 & 11,9 \\
\hline & - $\quad$ Kenaikan BB 1-5 kg & 58 & 63,1 \\
\hline & - $\quad$ Kenaikan BB $>5-10 \mathrm{~kg}$ & 21 & 22,8 \\
\hline & - $\quad$ Kenaikan BB >10 kg & 2 & 2,2 \\
\hline & $\begin{array}{r}\text { Total } \\
\end{array}$ & 92 & 100 \\
\hline
\end{tabular}


Tabel 4. Distribusi Frekuensi Responden berdasarkan Efek Samping Nyeri Payudara di Wilayah Kerja Puskesmas Harapan Raya Pekanbaru tahun 2019

\begin{tabular}{llcc}
\hline NO & \multicolumn{1}{c}{ Kategori } & Frekuensi & \% \\
\hline 1 & Nyeri Payudara sebelum menggunakan Implan & $\mathbf{0}$ & $\mathbf{0}$ \\
& - Ya & $\mathbf{9 2}$ & $\mathbf{1 0 0}$ \\
\hline & - Tidak & & \\
\hline & Nyeri Payudara Setelah Menggunakan Implan & & $\mathbf{5 1 , 1}$ \\
& (Saat diluar Haid) & 47 & $\mathbf{4 8 , 9}$ \\
& - Ya & $\mathbf{4 5}$ & $\mathbf{1 0 0}$ \\
\hline
\end{tabular}

Tabel 5. Distribusi Frekuensi Responden berdasarkan Efek Samping Gangguan Jerawat di Wilayah Kerja Puskesmas Harapan Raya Pekanbaru tahun 2019

\begin{tabular}{|c|c|c|c|}
\hline No & Kategori & Frekuensi & $\%$ \\
\hline 1 & $\begin{array}{llll}\text { Gangguan Jerawat } & \text { sebelum menggunakan } \\
\text { implant } & & & \\
\text { - Ya } & & & \\
\text { - Tidak } & & & \\
\end{array}$ & $\begin{array}{l}12 \\
80 \\
\end{array}$ & $\begin{array}{l}13,1 \\
86,9\end{array}$ \\
\hline 2 & $\begin{array}{l}\text { Gangguan Jerawat Setelah menggunakan implan } \\
-\quad \text { Ya } \\
- \text { Tidak }\end{array}$ & $\begin{array}{l}61 \\
31 \\
\end{array}$ & $\begin{array}{l}66,3 \\
33,7 \\
\end{array}$ \\
\hline & Total & 92 & 100 \\
\hline
\end{tabular}

Tabel 6 Distribusi Frekuensi Responden berdasarkan Efek Samping Gangguan Depresi di Wilayah Kerja Puskesmas Harapan Raya Pekanbaru tahun 2019

\begin{tabular}{|c|c|c|c|}
\hline No & Kategori & Frekuensi & $\%$ \\
\hline \multirow[t]{3}{*}{1} & $\begin{array}{l}\text { Gangguan Depresi sebelum menggunakan } \\
\text { implant }\end{array}$ & & \\
\hline & $-\mathrm{Ya}$ & 0 & 0 \\
\hline & - Tidak & 92 & 100 \\
\hline \multirow[t]{3}{*}{3.} & $\begin{array}{l}\text { Gangguan Depresi setelah menggunakan Implan } \\
\text { (Gelisah/gangguan emosional) }\end{array}$ & & \\
\hline & $-\mathrm{Ya}$ & 87 & 94,6 \\
\hline & - Tidak & 5 & 5,4 \\
\hline
\end{tabular}

Berdasarkan hasil penelitian diketahui bahwa mayoritas akseptor MKJP Implan berada pada usia reproduksi sehat (20-35 tahun) yaitu 72 orang $(78,3 \%)$, paritas multigravida yaitu 79 orang $(85,9 \%)$, dan lama menggunakan MKJP Implan $\leq 3$ tahun yaitu 76 orang $(82,6 \%)$. Berdasarkan tabel 2 diketahui bahwa responden di Wilayah kerja Puskesmas Harapan Raya Pekanbaru berada pada kategori tidak mengalami gangguan haid sebelum menggunakan $\mathrm{KB}$ implant yaitu 92 orang (100\%), dan setelah menggunakan Implan Responden mengalami Gangguan Haid berupa: Amenorea 76 orang (82,6\%), spotting 81 orang $(88,1 \%)$, menoragia 16 orang $(17,4 \%)$, siklus haid tidak teratur $(<20$ atau $>28$ hari) 16 orang $(17,4 \%)$.

Dari tabel 3 diketahui bahwa responden di wilayah kerja Puskesmas Harapan Raya Pekanbaru berada pada kategori tidak mengalami gangguan perubahan berat badan yaitu 92 orang $(100 \%)$, setelah menggunakan kontrasepsi implant responden mengalami gangguan perubahan Bert Badan sebanyak 81 orang $(89,1 \%)$ yaitu kenaikan berat badan 1$5 \mathrm{~kg}$ sebanyak 58 orang $(63,1 \%)$, kenaikan berat badan $>5-10 \mathrm{~kg}$ sebanyak 21 orang $(22,8 \%)$, kenaikan berat badan $>10 \mathrm{~kg}$ sebanyak 2 orang (2,2\%). Berdasarkan tabel 4 diketahui bahwa responden di wilayah kerja Puskesmas Harapan Raya Pekanbaru 
tahun 2019 berada pada kategori yang tidak mengalami nyeri payudara sebelum menggunakan implant yaitu sebanyak 92 orang (100\%) dan setelah menggunakan Implan Responden mengalami nyeri payudara (diluar saat haid) yaitu 47 orang $(51,1 \%)$.

Dari tabel 5 diketahui bahwa mayoritas responden di wilayah kerja Puskesmas Harapan Raya Pekanbaru tidak menggalami gangguan jerawat sebelum menggunakan implan yaitu 80 orang $(86,9 \%)$. Dan setelah menggunakan implan mengalami efek samping gangguan jerawat yaitu 61 orang $(66,3 \%)$. Dari tabel 6 diketahui bahwa responden di wilayah kerja Puskesmas Harapan Raya Pekanbaru berada pada kategori tidak mengalami gangguan depresi sebelum menggunakan KB implan yaitu 92 orang (100\%). Setelah penggunaan KB Implan mengalami depresi kategori Gelisah/ gangguan emosional sebanyak 87 orang $(94,6 \%)$.

\section{Pembahasan}

\section{a. Efek Samping Gangguan Haid pada Akseptor Implan}

Dari hasil penelitian diketahui bahwa Responden tidak mengalami gangguan siklus haid sebelum menggunakan KB Implan yaitu sebanyak 92 orang (100\%). dan setelah menggunakan kontrasepsi Implan Responden mengalami gangguan haid berupa: Amenorea 76 orang $(82,6 \%)$, spotting 81 orang $(88,1 \%)$, menoragia 16 orang $(17,4 \%)$, siklus haid tidak teratur ( $<20$ atau $>28$ hari) 16 orang $(17,4 \%)$.

Berdasarkan hasil penelitian efek samping penggunaan kontrasepsi Implan adalah Amenorea yaitu 76 orang $(82,6 \%)$. Amenorea adalah suatu keadaan tidak haid selama 3 bulan berturut-turut. Amenorea dibedakan menjadi dua: Amenorea primer yaitu bila perempuan usia 18 tahun ke atas tidak pernah mendapat haid sama sekali. Penyebabnya adalah kelainan genetik atau anatomi. Sedangkan amenorea sekunder dapat disebabkan secara fisiologis: Terjadi sebelum pubertas, dalam masa kehamilan, dalam masa menyusui, dalam masa menopause, gangguan pada aksis hipotalamus-hipofisis-ovarium, kelainan kongenital dan gangguan sistem hormonal.

Salah satu efek penggunaan implant pada endometrium adalah penurunan ketebalan endometrium yang lebih konsisten. Endometrium tetap tipis meskipun terjadi peningkatan estradiol selama penggunaan Implan. Selain itu, endometrium tipis ini tidak atrofi. Penggunaan implant juga menyebabkan terjadinya amenore tidak konsisten dengan keadaan hipoestrogenik. Hasil penelitian juga menunjukkan bahwa terjadi pola perdarahan terkait dengan puncak estradiol. Dengan tidak adanya puncak estradiol, amenore dapat terjadi dengan konsentrasi estradiol yang tinggi (fase folikel akhir) secara konsisten tinggi (fase folikel akhir) yang konsisten. Setelah puncak estradiol, perdarahan penghentian terjadi pada banyak (tetapi tidak semua) kasus dalam 3-5 hari. (Mäkäräinen.D, et.all, 1998)

Penelitian ini juga didukung oleh penelitian Hakimah (2015) yang berjudul Pengaruh Penggunaan Implan Etonogestrel $68 \mathrm{mg}$ terhadap gangguan menstruasi pada peserta metode kontrasepsi jangka panjang yang menyatakan bahwa efek samping dari penggunaan Implan adalah amenore sebanyak $48 \%$.

Gangguan Haid lain yang terjadi karena penggunaan kontrasepsi Implan adalah Spotting. Bedasarkan hasil penelitian terjadi gangguan haid spotting sebanyak 81 orang $(88,1 \%)$. Menurut Maharani (2007) Spotting disebut dengan perdarahan bercak-bercak yang terjadi pada 3-6 bulan pertama, Penyebab terjadinya perdarahan bercak (spotting) adalah terjadinya pelebaran pembuluh vena kecil diendometrium dan vena tersebut akhirnya rapuh sehingga terjadi perdarahan lokal, bila efek gestagen 
kurang, stabilitas stroma berkurang yang pada akhirnya terjadi perdarahan.

Hasil penelitian ini didukung oleh penelitian yang dilakukan oleh Perkasa,T (2016) dengan judul gambaran efek samping pada akseptor kontrasepsi hormonal di Puskesmas Colomadu 2 Kabupaten Karanganyar yang hasilnya aksptor MKJP implan mengalami spotting adalah sebanyak $14,3 \%$.

Efek samping lain dari gangguan siklus haid karena penggunaan kontrasepsi Implan adalah menoragia yaitu sebanyak 16 orang $(17,4 \%)$. Menoragia adalah perdarahan haid yang lebih banyak dari normal, atau lebih lama dari normal (lebih dari 8 hari) banyak yang dialami pada 3 bulan pertama setelah pemasangan implan. Siswati (2009)

Menoragia ini disebabkan karena progesterone yang menyebabkan terbentuknya kembali pembulu darah kapiler yang normal dengan sel-sel endotel yang mengandung kadar glikoprotein yang cukup sehingg sel-sel endotel terlindung dari kerusakan, sehingga akan mempengaruhi mekanisme kerja hormone dan siklus haid yang normal dan perdarahan akan menjadi lebih banyak. (Irianto, 2014). Penelitian ini sejalan dengan penelitian Perkasa, T. (2016) sebanyak 9,5\% responden mengalami gangguan haid menoragia.

Berdasarkan hasil penelitian sebanyak 16 orang $(17,4 \%)$ mengalami gangguan siklus haid tidak teratur yaitu ( $<20$ atau $>28$ hari). Menurut Irianto (2014) Gangguan siklus haid terjadi karena ketidak seimbangan hormonal sehingga endometrium mengalami histologia dan kadar FSH yang tingi dapat mengakibatkan terjadinya stimulasi ovarium yang berlebihan (hiperstimulasi) sehingga dijumpai kadar estrogen yang sangat tinggi). Sedangkan menurut (Sinaga E, 2017) Polimenorea merupakan kelainan siklus menstruasi yang menyebabkan wanita berkali - kali mengalami menstruasi dalam sebulan, bias dua atau tiga kali atau bahkan lebih. Normalnya, siklus menstruasi berlangsung selama 21-35 hari dengan durasi sekitar 2-8 hari. Wanita yang mengalami polimenorea memiliki siklus menstruasi yang pendek dari 21 hari dengan pola yang teratur dan jumlah perdarahan yang relatife sama atau lebih banyak. Menurut Astuti (2015) yang mengalami siklus menstruasi kurang dari 21 hari terjadi pada waktu 3 bulan pertama.

Penelitin ini juga sejalan dengan oleh penelitian Rahayu.S (2015) yang menyatakan bahwa efek samping penggunaan kontrasepsi implant adalah mengalami siklus haid tidak teratur $(<20$ hari atau siklus haid $>28$ hari) yaitu sebanyak 15 akseptor $(45,4 \%)$. Hal ini terjadi pada awal pemakaian kontrasepsi implant, salah satu penyebab terjadinya gangguan siklus haid ini adalah karena ketidak seimbangan hormon sehingga endometrium mengalami histologi.

Menurut asumsi peneliti peneliti mayoritas yang mengalami gangguan siklus haid tidak teratur seperti amenorea, spotting, menoragia, keluhan yang dialami oleh responden ini dapat disebabkan karena efek samping $\mathrm{KB}$ implan, gangguan siklus haid umumnya dialami oleh responden selama 3-6 bulan pertama setelah pemasangan implan dan masalah ini akan beransur menghilang.

\section{b. Efek Samping Gangguan Berat Badan pada Pengguna MKJP Implan}

Berdasarkan hasil penelitian mayoritas responden di wilayah kerja Puskesmas Harapan Raya Pekanbaru berada pada kategori tidak mengalami gangguan perubahan berat badan yaitu 92 orang (100\%), setelah menggunakan kontrasepsi implant responden mengalami gangguan perubahan Berat Badan sebanyak 81 orang $(89,1 \%)$ yaitu kenaikan berat badan 1-5 kg sebanyak 58 orang $(63,1 \%)$, kenaikan berat badan $>5$ $10 \mathrm{~kg}$ sebanyak 21 orang $(22,8 \%)$, 
kenaikan berat badan $>10 \mathrm{~kg}$ sebanyak 2 orang $(2,2 \%)$.

Berat badan bertambah atau menurun secara cepat dapat diliat dalam waktu 7 bulan pertama setelah pemasangan implan. Hormon progreston mempermudakan perubahan karbohidrat dan gula menjadi lemak dan merangsang nafsu makan serta menurunkan aktifitas fisik, sehingga adanya implan dapat menyebabkan berat badan bertambah. Penambahan berat badan ini disebabkan karena hormone yang mengandung progesterone dapat merangsang pusat pengendali nafsu makan dihipotalamus yang menyebabkan akseptor makan lebih dari biasanya. (Irianto,2014).

Menurut Prawiroharjo,2007 efek penambahan berat badan dapat disebabkan karena hormon yang terkandung dapat merangsang pusat pengendali nafsu makan dihipotalamus yang menyebabkan akseptor makan lebih banyak dari biasanya.

Hasil penelitian ini juga didukung oleh penelitian yang dilakukan oleh Bhatia. P et.all. (2011) kepada 200 responden yang dievaluasi selama 1 tahun, didapatkan hasil terjadi kenaikan berat badan $>5 \mathrm{~kg}$ yang terjadi pada $7,5 \%$ kasus, akan tetapi hal ini tidak menyebabkan subjek untuk menghendtikan penggunaan implant.

Penelitian lain yang dilakukan oleh larasati (2017) dengan judul hubungan penggunaan kontrasepsi implan dengan kenaikan berat badan pada wanita usia subur di puskesmas MLAT II kabupaten sleman Yogyakarta diketahui bahwa responden yang mengalami kenaikan berat badan selama penggunaan kontrasepsi implant sebanyak 23 responden $(63,9 \%)$ lebih besar dibandingkan dengan responden yang tidak mengalami kenaikan yaitu sebanyak 13 responden $(36,1 \%)$.

Menurut asumsi peneliti mayoritas yang mengalami kenaikan berat badan dapat disebabkan adanya faktor lain yaitu gangguan hormonal, pola makan dan pola aktivitas yang menjadi peyebab kenaikan berat badan ini dapat dicegah dengan megatur pola makan serta melakukan akitivitas fisik seperti olahraga.

\section{c. Efek Samping Nyeri Payudara pada Pengguna MKJP Implan}

Berdasarkan hasil penelitian, seluruh responden di wilayah kerja Puskesmas Harapan Raya Pekanbaru tidak mengalami gangguan nyeri payudara sebelum menggunakan implan yaitu 92 responden $(100 \%)$ adalah akan tetapi setelah menggunakan Implan Responden mengalami nyeri payudara (diluar saat haid) yaitu 47 orang $(51,1 \%)$.

Efek samping nyeri payudara pada akseptor kontrasepsi implant dapat terjadi karena adanya gangguan keseimbangan hormon (EstrogenProgesteron) kemudian mempengaruhi kalenjar payudara sehingga terasa kencang dan tegang, kadang-kadang disertai rasa nyeri pada daerah payudara, ini terjadi pada > 6 bulan setelah pemasangan implan. (Irianto, 2014)

Penelitian yang dilakukan oleh Gezginc,O et.all:2007 terhadap 80 pengguna implan Efek samping nonmenstruasi yang dirasakan oleh akseptor Implanon terdiri dari nyeri payudara pada 15 pasien $(18,75 \%)$, jerawat pada delapan (10\%), sakit kepala dan pusing pada tiga $(3,75 \%)$; gangguan mood depresi, nyeri panggul dan hilangnya libido disebutkan masing-masing oleh dua wanita $(2,5 \%)$.

Penelitian ini juga sejalan dengan penelitian Perkasa, tomy (2016) yang mengalami ketegangan pada payudara setelah mengunakan KB Implan adalah sebanyak $14,3 \%$.

Menurut asumsi peneliti mayoritas yang mengalami nyeri payudara dapat menganggu responden dalam melakukan aktivitas secara normal, ini biasanya dapat disebabkan karena ketidak seimbangan hormonal sehingga membuat responden mengalami nyeri payudara, 
tetapi responden tidak perlu khawatir karena ini akan bisa hilang dengan sendirinya.

\section{d. Efek Samping Gangguan Jerawat pada Pengguna MKJP Implan}

Berdasarkan hasil penelitian, mayoritas responden di wilayah kerja Puskesmas Harapan Raya Pekanbaru sebelum menggunakan Implan tidak mengalami gangguan jerawat yaitu 80 responden $(87 \%)$, akan tetapi setelah menggunakan implan mayoritas responden mengalami efek samping gangguan timbulnya jerawat yaitu 61 orang $(66,3 \%)$

Timbulnya jerawat yang berlebihan pada wajah terjadi pada waktu 6 bulan pertama di karenakan faktor progestornya, terutma 19-nortestosteron menyebakan kadar lemak, Jerawat ini tanpa peningkatan produksi minyak, merupakan keluhan kulit yang paling umum diantara pengguna implant. Jerawat disebakan oleh aktivitas androgenik levonorgestrel yang menghasilkan suatu dampak langsung dan juga menyebabkan penurunan dalam kadar globulin peningkatan hormone seks (SHBG, sex hormone binding globulin), menyebabkan peningkatan kadar stroid bebas (baik levonorgestrel maupun testosteron). (Irianto,2014).

Penelitian ini sejalan dengan penelitian perkasa tomy (2016) dengan judul gambaran efek samping pada akseptor kontrasepsi hormonal di Puskesmas Colomadu Kabupaten Karanganyar yang mengalami masalah jerawat adalah sebanyak $16,7 \%$.

Menurut asumsi peneliti mayorits yang mengalami timbulnya jerawat pada penggunaan implan dapat disebabkan oleh hormone progesterone, efek samping ini umumnya tidak menggangu aktivitas, tetapi dalam hal lain mengurangi kepercayaan diri dalam penampilannya, ini juga tidak membahayakan bagi responden jerawat yang timbul akan hilang dengan sendirinya ini dapat terlihat 6 bulan setelah pemasangan implant

\section{e. Efek Samping Gangguan Depresi pada Pengguna MKJP Implan}

Berdasarkan hasil penelitian, seluruh responden di wilayah kerja Puskesmas Harapan Raya Pekanbaru tidak mengalami gangguan depresi berupa mdah lelah dan gangguan emosianal/gelisah sebelum menggunakan implan yaitu 92 responden $(100 \%)$ adalah akan tetapi setelah menggunakan implan 87 orang $(94,6 \%)$ mengalami gangguan depresi berupa mudah lelah, gelisah dan gangguan emosional.

Depresi ini meliputi gejala atau keluhan rasa lesu,tidak bersemangat dalam kerja atau dalam kehidupan. Adanya hormone progesterone yang berasal dari kapsul implan menyebabkan terjadinya retensi garam sehingga ada bagian otak jantung yang mengelembung dan menekan pusat susunan saraf tertentu (Irianto,2014). Depresi mudah lelah atau letih adalah kondisi tubuh yang tidak dapat melakukan suatu kegiatan. Sedangkan emosional merupakan suatu kondisi kecemasan yang berlebihan, ketakutan, ini dapat dipengaruhi secara psikologis, ini teradi pada 3 bulan pertama

Penelitian ini didukung oleh penelitian muslihati (2016) didapatkan bahwa responden terbayak mengalami stress 55 orang $(61,8 \%)$. Kondisi stress ini cenderung menjadi mudah marah dan dapat memicu timbulnya rasa sakit kepala karena terjadi vasokontrisik pada pembuluh darah yang mengakibatkan perfusi oksigen ke jaringan otak.

Menurut asumsi peneliti mayoritas yang mengalami depresi pada penggunaan implan disebabkan oleh peningkatan hormone progesterone dalam tubuh kondisi ini cenderung menjadi mudah marah dan dapat memicu timbunya rasa sakit kepala. 


\section{Simpulan}

Simpulan efek samping penggunaan kontrasepsi Implan yang dirasakan oleh responden antara lain Gangguan Siklus Haid yaitu Amneorea sebanyak 76 responden $(82,6 \%)$, Spotting yaitu 81 responden $(88,1 \%)$, Menoragia yaitu 16 responden $(17,4 \%)$ dan siklus tidak teratur $(<20$ hari atau $>35$ hari) yaitu 16 responden (17,4\%), Efeksamping Gangguan Berat Badan berupa Peingkatan Berat Badan yaitu 81 responden $(89,1 \%)$, Efeksamping gangguan Nyeri Payudara yaitu 47 responden (51,1\%), Efek samping gangguan Timbulnya Jerawat yaitu 61 responden $(66,3 \%)$, dan Efek samping gangguan Depresi berupa gelisah atau gangguan emosi yaitu 87 responden $(94,6 \%)$.

Saran dalam penelitian ini adalah dalam memberikan asuhan kebidanan bidan harus memperhatikan efek samping penggunaan kontrasepsi implant dan dapat memberikan konseling dan penatalaksanaan yang sesuai dengan efek samping yang dirasaka oleh aksepttor sehingga akseptor mendapatkan asuhan yang tepat dapat lebih terfokus dan terarah.

\section{Referensi}

Anggaraini dan Martini. 2012. Pelayanan keluarga berencana. Yokyakarta: Rohima Press.

Astuti, I. 2015. Hubungan lama penggunaan kontrasepsi implant dengan siklus menstrusi.https://www.google.com/s earch?q=Hubungan+lama+pengguna an+kontrasepsi+implan+dengan+sikl us + menstrusi. $+\&$ ie $=$ utf $-8 \&$ oe $=$ utf8\&cli. Akses tanggal 12 februari 2019

Badan Pusat Stastistik. 2018. Proyekti Penduduk Indonesia 2015-2045. Diperoleh dari https :// indonesia. Unfpa. Org/ sites /default/ files/ pubpdf/proyeksi\% 202015-2045_.pdf

Bhatia.P, Nangia.S, Aggarwal.S and Tewari.C. 2011. Implanon:
Subdermal Single Rod Contraceptive Implant. Journal Obstetry Gynecology India. 61(4): 422-425

Dinkes Provinsi Riau. 2016. Profil Kesehatan Provinsi Riau 2016. Diperoleh dari http://www.depkes.go.id/resources/d ownload/profil/PROFIL KES PROVINSI 2016/04 Riau 2016.pdf

Gezginc.K, Balci.R, Karatayli. Colakoglu. MC. 2007. Contraceptive efficacy and side effect of implanon. The Europen Journal of Contraception and Reproductive Health Care. 12(4): 362-365

Hakimah, H. 2015. Pengaruh Penggunaan Implan Satu Batang (ETONOGESTREL 68 MG) Terhadap Gangguan Menstruasi Pada Peserta Metode Kontrasepsi Jangka Panjang. Akses 12 februari 2019

https://www.google.com/search?q=p engaruh+penggunaan+implan+satu+ batang $+\&$ ie $=$ utf- $8 \&$ oe $=$ utf 8 \&client $=$ firefox-b-ab

Irianto, K. 2014. Pelayanan Keluarga Berencana. Alfabeta.

Kemenkes RI. (2017). Profil kesehatan Indonesia 2017. https://www.google.com/url?sa=t\&rc $\mathrm{t}=\mathrm{j} \& \mathrm{q}=\& \mathrm{esrc}=\mathrm{s} \&$ source $=$ web $\& \mathrm{~cd}=1$ $\&$ cad $=$ rja\&uact $=8 \& v e d=2$ ahUKEwj 89NHjspzgAhXEK48KHcq2AGEQF jAAegQIChAC\&url=http $\% 3 \mathrm{~A} \% 2 \mathrm{~F} \%$ 2Fwww.depkes.go.id\%2Fresources\% 2Fdownload\%2Fpusdatin\%2Fprofilkesehatan-indonesia\%2FProfilKesehatanIndonesia-tahun 2017. pdf\&usg $=\mathrm{AOvVaw} 0 \mathrm{JLcX} 2 \mathrm{wbvfC} 4 \mathrm{Mi} 4 \mathrm{NbvC}$ U1C. Akses tanggal 12 februari 2019

Kemenkes RI. 2013. Situsi Keluarga Berencana Di Indonesia. https:// www. scribd. com document/254486993/buletin-kespro Akses tanggal 12 februari 2019

Larasati,S. 2017. Hubungan Penggunaan kontrasepsi Implan Dengan 
Kenaikan Berat Badan Pada Wanita Usia Subur. Akses 12 februari 2019 https://www.google.com/url?sa=t\&rc $\mathrm{t}=\mathrm{j} \& \mathrm{q}=\&$ esrc $=\mathrm{s} \&$ source $=\mathrm{web} \& \mathrm{~cd}=1$ $\&$ cad $=$ rja $\&$ uact $=8 \& v e d=2 a h U K E w j$ 19bO7sLDgAhXBMI8KHeQgARA QFjAAegQIChAC\&url=http\%3A\%2 F\%2Fdigilib.unisayogya.ac.id\%2F26 39\%2F1\%2FNASKAH\%2520PUBL IKASI.pdf\&usg=AOvVaw0BPT6iLs nIDc1cpiOnuty \%20Akses\%20tangg al\%2012\%20februari\%202019.

Mäkäräinen. L, et.all. 1998. Ovarian Function During the Use of a Single Contraceptive Implant: Implanon Compared with Norplant. Journal Fertility and Sterility. 69 (4): 714721

Maharani . 2007. Analisis Faktor - Faktor Pada Ibu Yang Mempengaruhi Terhadap Pemakaian Metode Kontrasepsi Implan Di Kabupaten Sukoharjo. Stikes Aisyiyah Surakarta.

Mailani, N, dkk. 2010. Pelayanan Keluarga Berencana. Yogyakarta: Fitramaya.

Noviawati, D.A. 2011. Panduan Lengkap Pelayanan KB Terkini .Jogyakarta: Nuha Medika.

Notoatmodjo, S. 2012. Metodologi Penelitia Kesehatan. Jakarta: Rineka Cipta.

Sinaga,E. 2017. Manajemen Kesehatan Menstruasi. Akses 12 februari 2019 https://www.google.com/search?q=ht tps\%3A\%2F\%2Fbooks.google.co.id \%2Fbooks\%2Fabout\%2FMANAJE MEN KESEHATAN MENSTRUA SI.html\%3Fid\%3DBmVaDwAAQB AJ\%26redir_esc\%3Dy\&oq=ht

Sulistyawati, A. 2011. Pelayanan Keluarga Berencana. Jakarta: Salemba Medika.

Setiyanigrum, E. 2014. .Pelayanan Keluarga Berencana dan Kesehatan Reproduksi. Jakarta:Trans Info Media.
Suratun,dkk. 2008. Pelayanan Keluarga Berencana Dan Pelayanan Kontrasepsi. Trans Info Medial.

Saifuddin,B,A.dkk. 2010. .Buku Panduan Praktis Pelayana Kontrasepsi. Jakarta: PT Bina Pustaka Sarwono Prawirohardjo

Siswati. 2009. Perbedaan Siklus Menstruasi Antara Ibu Yang Menggunakan Alat Kontrasepsi Implan Dengan Kontrasepsi Lain DiDusun Gergunung Klaten Utara Klaten Jawah Tengah. Jurnal. Muhammadiyah. 